\title{
Innovative technological capability in firms of the tourism sector: a study of the hotels in the city of Rio de Janeiro during the $1990-2008$ period*
}

\author{
Paulo N. Figueiredo** \\ Saulo Gomes*** \\ Roberto Farias****
}

\begin{abstract}
Summary: 1 . Introduction; 2 . The objective of this project; 3 . The tourism sector in Brazil and the city of Rio de Janeiro; 4. Technological capability at the organizational level; 5 . The nature of innovation, its characteristics and particularities; 6 . A technological capability framework for hospitality industry: hotel service firms; 7. Sources of technological capability accumulation; 8. Framework to examine technological capability accumulation sources; 9. Final considerations.
\end{abstract}

Sumário: 1. Introdução; 2. Objetivo do projeto. 3. O setor turístico no Brasil e na cidade do Rio de Janeiro. 4. Capacidade tecnológica no nível organizacional. 5. Natureza da inovação, suas características e particularidades 6 . Um referencial de capacidade tecnológica para a indústria de hospitalidade: empresas de serviços de hotelaria. 7. Fontes de acumulação de capacidade tecnológica. 8. Referencial de análise de fontes de acumulação de capacidades tecnológica. 9. Considerções finais.

\footnotetext{
* Article received in May 2010 and accepted in Aug. 2010.

** Faculty member of the Brazilian School of Public and Business Administration (Ebape) at the Getulio Vargas Foundation (FGV). PhD in technology and innovation management from Science and Technology Policy Research (SPRU), University of Sussex, UK. Senior research associate, University of Oxford, UK. Project leader: Innovative technological capability in firms of the tourism sector in the city of Rio de Janeiro during the 1990-2008 period - Pronex Tourism (Faperj/FGV/PUC-RIO). Address: Praia de Botafogo, 190 - Botafogo - CEP 22250-900, Rio de Janeiro, RJ, Brazil. E-mail: paulo.figueiredo@fgv.br.

*** Masters degree in public administration from the Getulio Vargas Foundation, Brazil. Researcher of the Ebape/FGV's Management of Technological Learning and Industrial Innovation in Brazil Research Program. Researcher of the project: Innovative technological capability in firms of the tourism sector in the city of Rio de Janeiro during the 1990-2008 period - Pronex Tourism (Faperj/FGV/PUC-Rio). Address: Praia de Botafogo, 190 - Botafogo - CEP 22250-900, Rio de Janeiro, RJ, Brasil. E-mail: sgomes@fgv.br.

**** Masters degree in communication from the State University of Rio de Janeiro. Researcher of the project: Innovative technological capability in firms of the tourism sector in the city of Rio de Janeiro during the 1990-2008 period — Pronex Tourism (Faperj/FGV/PUC-RIO). Address: Praia de Botafogo, 190 - Botafogo - CEP 22250-900, Rio de Janeiro, RJ, Brasil. E-mail: roberto.farias@fgv.br.
} 
KEY WORDS: tourism; hospitality; innovation; technological capability.

Palavras-chave: turismo; hospitalidade; inovação; potencialidade tecnológica.

This article presents the preliminary report of the research project entitled "Innovative technological capability in firms of the tourism sector: a study of the hotels in the city of Rio de Janeiro during the 1990-2008 period". The objective of this project is to apply and evaluate an analytical model of technological capability and underlying learning processes and examine the accumulation trajectory of innovative technological capability in the firms of tourism service industry, and the impact of learning processes undertaken by these firms on the technological capability levels achieved during the 1990-2008 period.

\section{Capacidade tecnológica inovadora em empresas do setor turístico}

Este artigo apresenta o relatório preliminar do projeto de pesquisa Capacidade Inovadora em Empresas do Setor Turístico: um Estudo dos Hotéis na Cidade do Rio de Janeiro no Período de 1990-2008, cujo objetivo é aplicar e avaliar um modelo analítico da capacidade tecnológica e dos processos de aprendizagem subjacentes, além de examinar a trajetória de acumulação de capacidades tecnológicas inovadoras nas empresas de turismo e o impacto dos processos de aprendizagem utilizados por essas empresas nos níveis de capacidade tecnológica atingidos no período.

\section{Introduction}

This document presents the preliminary report of the research project entitled "Innovative technological capability in firms of the tourism sector: a study of tourist class hotels in the city of Rio de Janeiro during the 1990-2008 period". This research project is being undertaken by the Getulio Vargas Foundation's (FGV) Brazilian School of Public and Business Administration (Ebape) under the Research Programme on Technological Learning and Industrial Innovation Management in Brazil, as part of the Pronex Tourism Research Project.

The reason for performing this study is first of all our limited, or insufficiently clear, understanding of the concept of innovation applied to the service sector, particularly to the tourism segment. Secondly, although there are several studies of innovation in the service sector from a knowledge economy, dynamic capabilities and globalized competition perspective, a significant part of these studies examine services innovation in technologically advanced economies such as the United States, United Kingdom, Spain, Finland and Germany (Tidd and Hull, 2003).

However, there is a dearth of studies of the development of an innovative technological capability in service activities in developing countries, especially at 
the organizational level (Figueiredo, 2007). This lack of an understanding of the real industrial dynamics of the services sector in developing economies prevents researchers from providing appropriate recommendations for corporate management and those responsible for formulating government policies (Bell, 2006).

Thus, this research project's aim is to undertake a wide-ranging examination of innovation processes that can be applied or related to service activities and present recommendations that contribute to increasing the tourism sector's level of competitiveness.

This preliminary report is organized in nine sections. Following this introduction, section two presents the project's overall aim, the analytical model applied in the study and the strategy and planning adopted to develop the project. Section three presents a brief description of the tourism sector in Brazil and the city of Rio de Janeiro. Sections four and five presents the main concepts related to technology, technological capability and innovation. The preliminary version of the framework that will be used to identify technological capability levels is described in section six. Section seven contains a brief discussion of the sources of technological capability accumulation and section eight presents the framework that will be used to identify the types and characteristics of the learning mechanisms used by firms in the sample. Lastly, section nine presents some final considerations regarding the project.

\section{The objective of this project}

This project's objective is to apply and evaluate an analytical model of technological capability and underlying learning processes, as well as examine the path of innovatory technological capacity accumulation in tourism sector firms, and the impact of the learning processes developed by these firms on technological capability levels achieved during the $1990-2008$ period. The study specifically examines 10 hotel firms, located in the touristic destination of the city of Rio de Janeiro.

\section{The analytical model and design of the project}

This research project's analytical model examines the relation between innovative capability accumulation and underlying learning processes during the 1990-2008 period in tourist class hotel firms located in the city of Rio de Janeiro. The project's analytical model is presented in figure 1. Applying this model is expected to contribute to a better understanding of the development of an innovative capacity in service companies, specifically in hotel firms of the Brazilian tourism sector. 


\section{Figure 1 \\ Analytical model used in the research project}

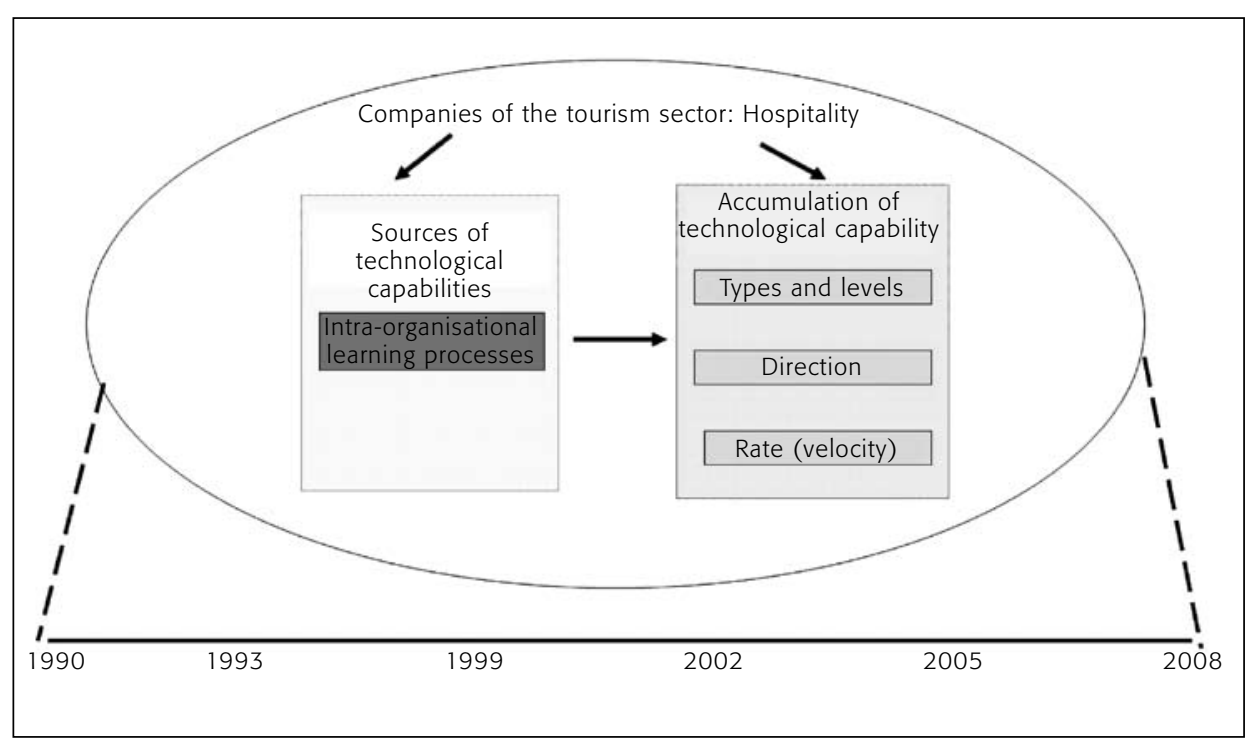

Sections four, five and seven of this report present a brief account of the concepts related to the elements of the proposed analytical model. The frameworks used to gather empirical evidence are presented in sections six and eight.

\section{Project strategy and planning}

The research project proposal involved three phases covering a 12-month period, from September 2009 to August 2010. The first phase, which has already been completed, was devoted to a study of the tourism sector in Brazil and the world, in order to understand those features and characteristics of the hotel operation's main activities that have the most significant innovative impact. This study was performed by reading the sector-related literature, consulting firm and trade association websites and through interviews with members of professional associations and tourism sector specialists. A framework was also developed during this phase in order to identify hotel firms' operational and innovative technological capability levels. Furthermore, 
the research defined a framework to examine the main learning processes undertaken by the firms in the sample.

During the second phase, the pilot work, interviews will be held with hotel sector specialists, as well as some hotel firm managers (general and operational managers) in order to gain a deeper understanding of hotel operations in Brazil and Rio de Janeiro, and assess and adjust the framework developed during the first phase of the project. The research will also define and prepare the final learning process-related data gathering tools.

Finally, the project's third and final phase will involve interviews with managers and other hotel firm professionals as well as the application of the other data-gathering tools to prepare the analysis stage. When the interview and data-gathering process has been completed, the research will perform qualitative and quantitative analyses in order to develop the project's final report. During this phase, around 10 hotels located in the city of Rio de Janeiro will be consulted to arrange interviews with general, operational, food and beverage, entertainment and leisure and administrative area managers, as well as other professionals linked to hotel operation-related activities.

\section{The tourism sector in Brazil and the city of Rio de Janeiro}

According to the World Tourism Organization (2008), Brazil is the second international tourist destination in Latin America. In 2008, the country received 5 million tourists (Embratur, 2009) who spent US\$ 5.8 billion, a 16.8\% increase over 2007 (CET, 2008). The tourism sector accounted for $3.2 \%$ of total income generated by exports of goods and services and 7\% of direct and indirect employment in the Brazilian economy. (MTur, 2007). The sector's foreign exchange revenues are shown below (figure 2).

The tourism sector's generation of revenues and jobs is heavily concentrated in the country's Southern and Southeastern regions, with Rio de Janeiro occupying second place in the country as a whole in terms of gross revenues (figure 4). The following services account for the larger part of net operating revenues: food (35.19\%), air transport (22.94\%), auxiliary transport (14.64\%) and leisure and entertainment (11.99\%), as shown in figure 5 . The hospitality sector occupies fifth place with an $8.31 \%$ share of net operational revenues, or US\$260 million, according to data for 2003 (IBGE, 2005). 
Figure 2

Brazil's foreign exchange tourism revenues (US\$ million FOB) 2003-2008

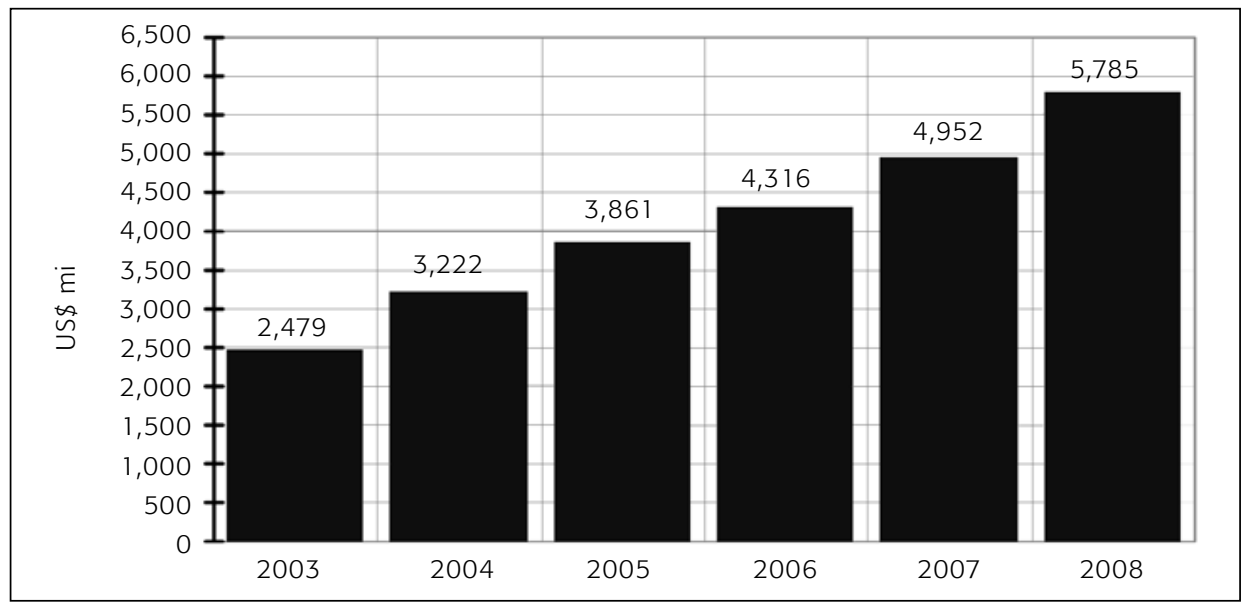

Source: Brazil's Central Bank (2008).

Figure 3

Gross revenues according to activity in the tourism sector in 2003

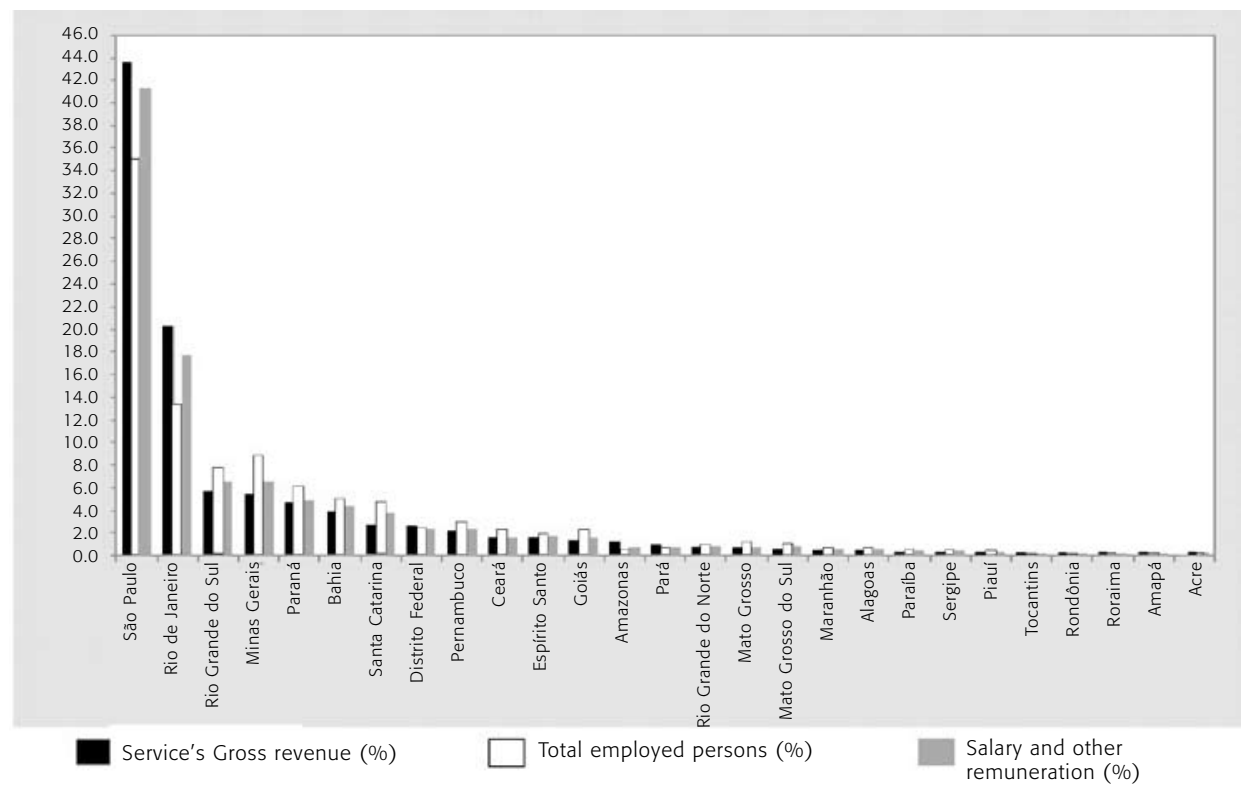

Source: IBGE (2005). 


\section{Figure 4}

Net operating revenues according to tourism sectors in 2003

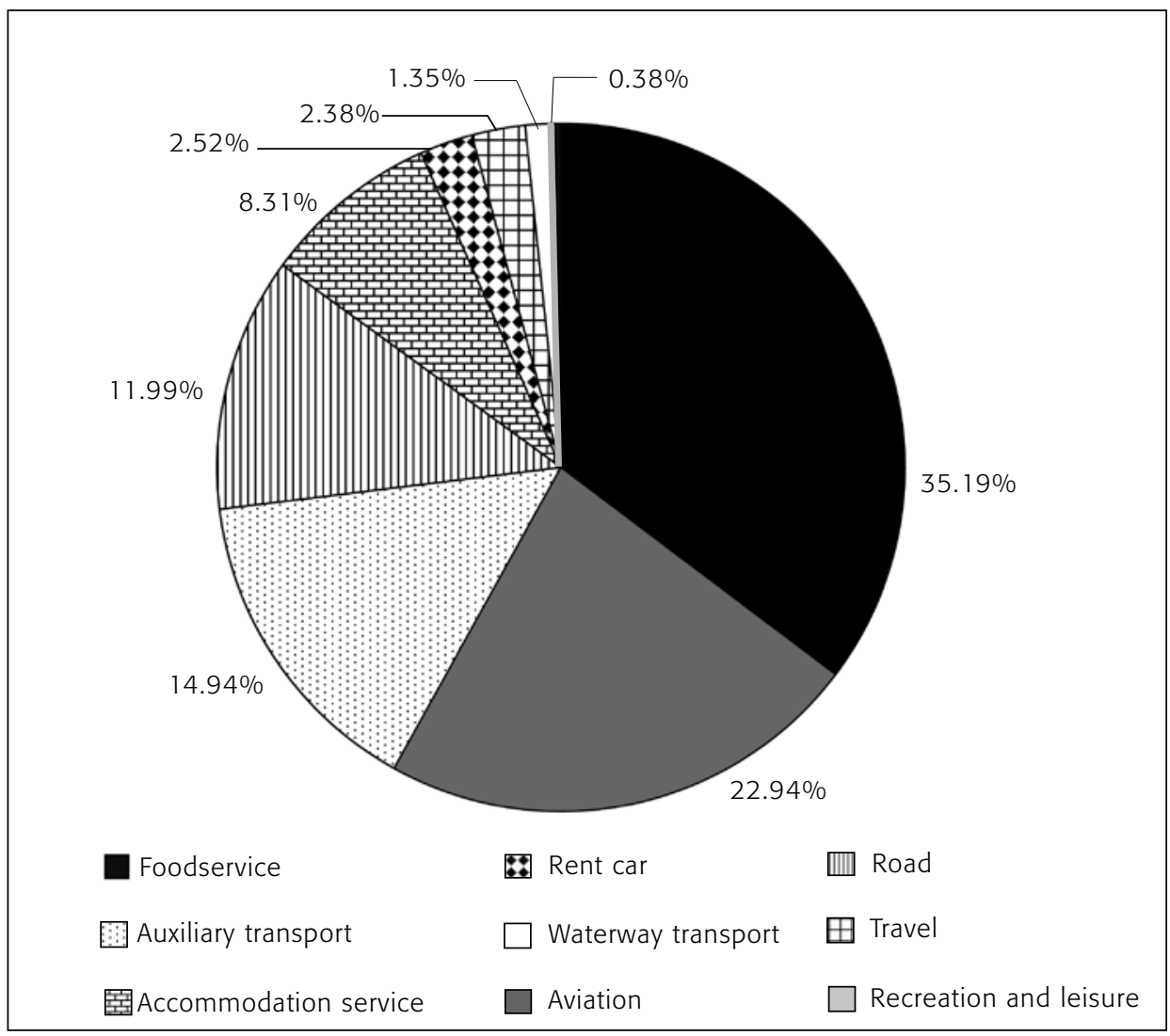

Source: IBGE (2005).

The mean of accommodation activity encompasses the firms that provide reception and accommodation for tourists and visitors in general - the hotels, resorts, inns and temporary rental accommodation. There are an estimated 25 thousand mean of accommodation in Brazil, of which 5.324 are currently registered with the mnistry of Tourism. Hotel networks are composed of 789 business groups, with domestic networks accounting for $55.90 \%$ of mean of accommodation and international networks for $44.01 \%$ (MTur, 2009). The hospitality sector generates 240.000 jobs in the domestic market. It is also a sector that concentrates the resources developed in the actual region where tourism tales place (figure 7), thus helping to improve income distribution and foster social development (MTur/Sebrae/Fife, 2006). 
Figure 5

Total impact on employment, production value and value added (in \%)

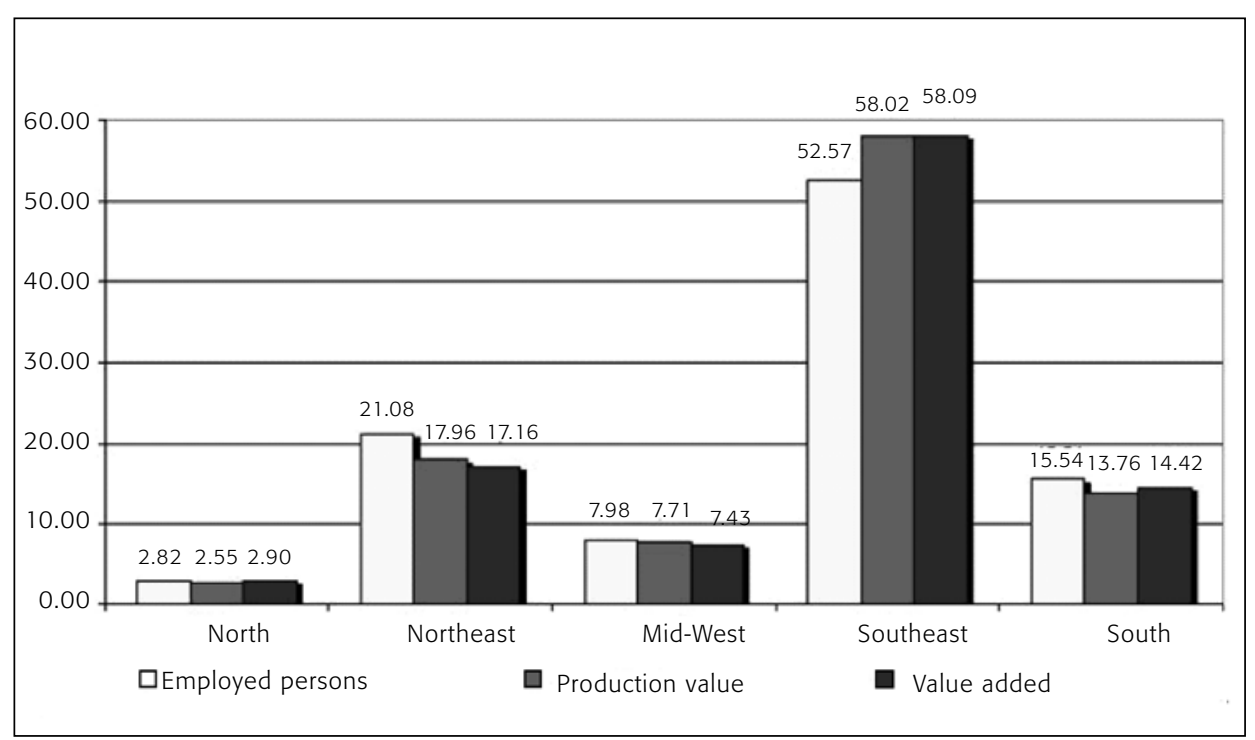

Source: Mtur/Sebrae/Fipe (2006).

Figure 6

Proportion of total income generated which is retained in the region itself

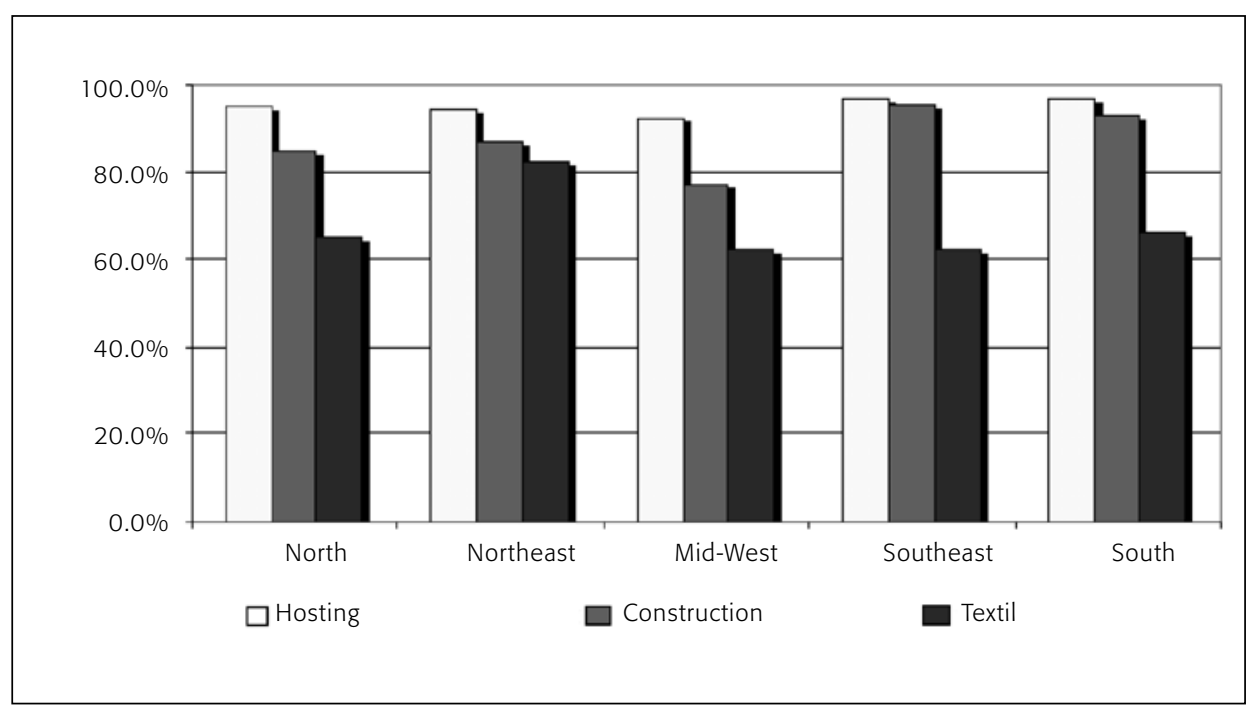

Source: Mtur /Sebrae/Fipe (2006). 
The city of Rio de Janeiro is one of the world's main tourist destinations, with a powerful brand and image abroad, and is undoubtedly Brazil's main domestic tourist destination. (figure 8). This reality is evidenced by the diversity and quality of its world class hotel network, the configuration of its network of tourist agents with their close links with major emitting countries, and the fact that it is served by the world's main airlines, who have established the city as South America's main tourist hub. Indeed, according to Brazilian Tourism Institute (Embratur), the state capital is the main gateway for foreign leisure tourists entering the country.

\section{Figure 7}

\section{Inflow of foreign tourists to the city of Rio de Janeiro during the 1991-2007 period}

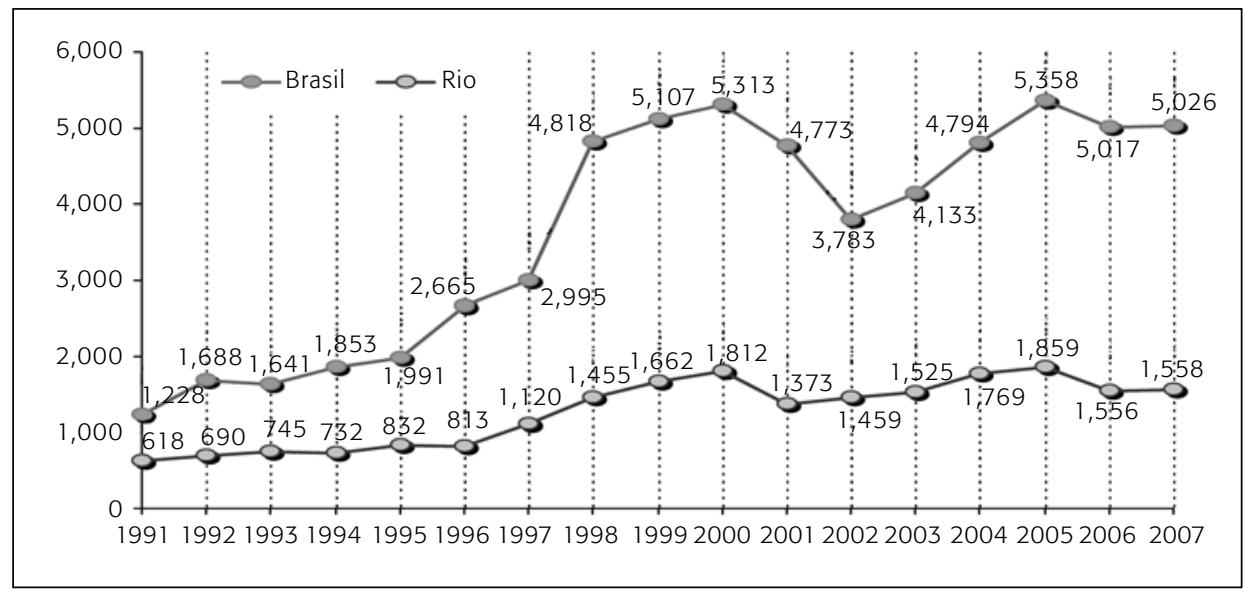

Source: Fipe e Embratur (2008).

Between 1997 and 2007, Rio de Janeiro's share in Brazil's most visited destinations oscillated annually between $28.77 \%$ (2001) and 38.57\% (2002), or an average share of $33.83 \%$. Figure 8 shows the city's stability as a tourist destination during the last decade. In 2007, according to Embratur (2007), 1.500.000 of the approximately 5.000.000 million tourists who visited Brazil came to Rio de Janeiro, whether for leisure (30.2\%) or for business activities, events and conventions, one of the main indicators of the increasing importance, stability and development of the tourism sector in Rio de Janeiro, as revealed by surveys of the sector, are the number of departures and arrivals of domestic and foreign visitors at Tom Jobim International Airport, as showed in figures 8 and 9 (Infraero, 2008). 
Figura 8

Foreign passenger flows at Tom Jobim International Airport during the 1997-2007 period

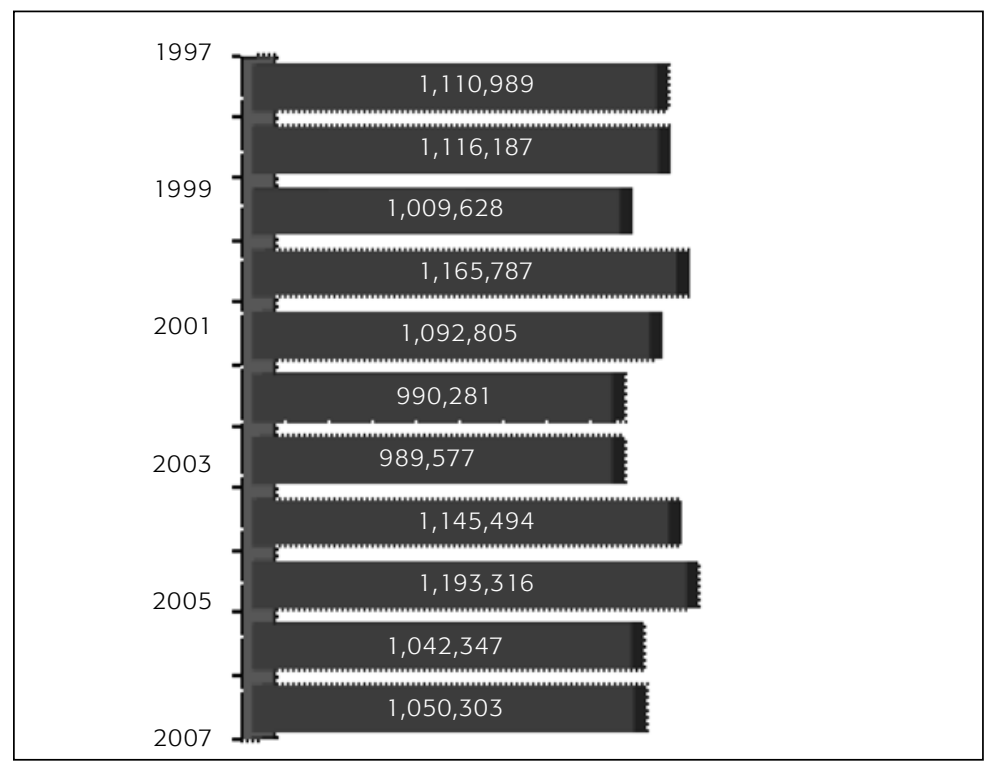

Source: Infraero (2008).

Figure 9

Flow of domestic passengers at Tom Jobim International Airport during the 1997-2007 period

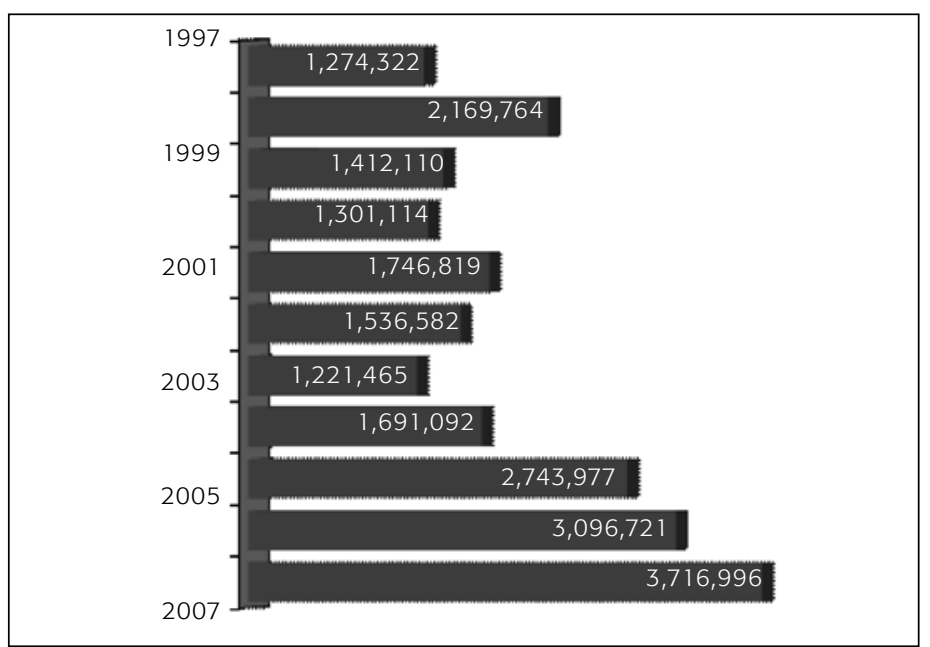

Source: Infraero (2008). 
The stability of foreign passenger arrivals and the increase in domestic passenger arrivals, showed in figure 9, reflect the growth of domestic tourism in the Brazilian market and the importance of the city of Rio de Janeiro as a domestic destination.

As shown in figure 10, foreign tourists travel to Rio de Janeiro for leisure (53.1\%), followed by business and events (28.5\%), and the most sought after touristic segments are sun and beach $(44.6 \%)$, culture $(22.1 \%)$ and nature, ecotourism or adventure (20.6\%) according to database of Economic Research Institute Foundation (2005-2007) and the Competitiveness Study of Destinations that Induce Regional Tourism (2009). In 2007, the main emitting countries for the city of Rio de Janeiro, were the United States (22.5\%), France (8.1\%) and Argentina (6.9\%) (MTur, 2007).

Figure 10

Main motivations for foreign tourists' leisure trip to the city of Rio de Janeiro in 2007

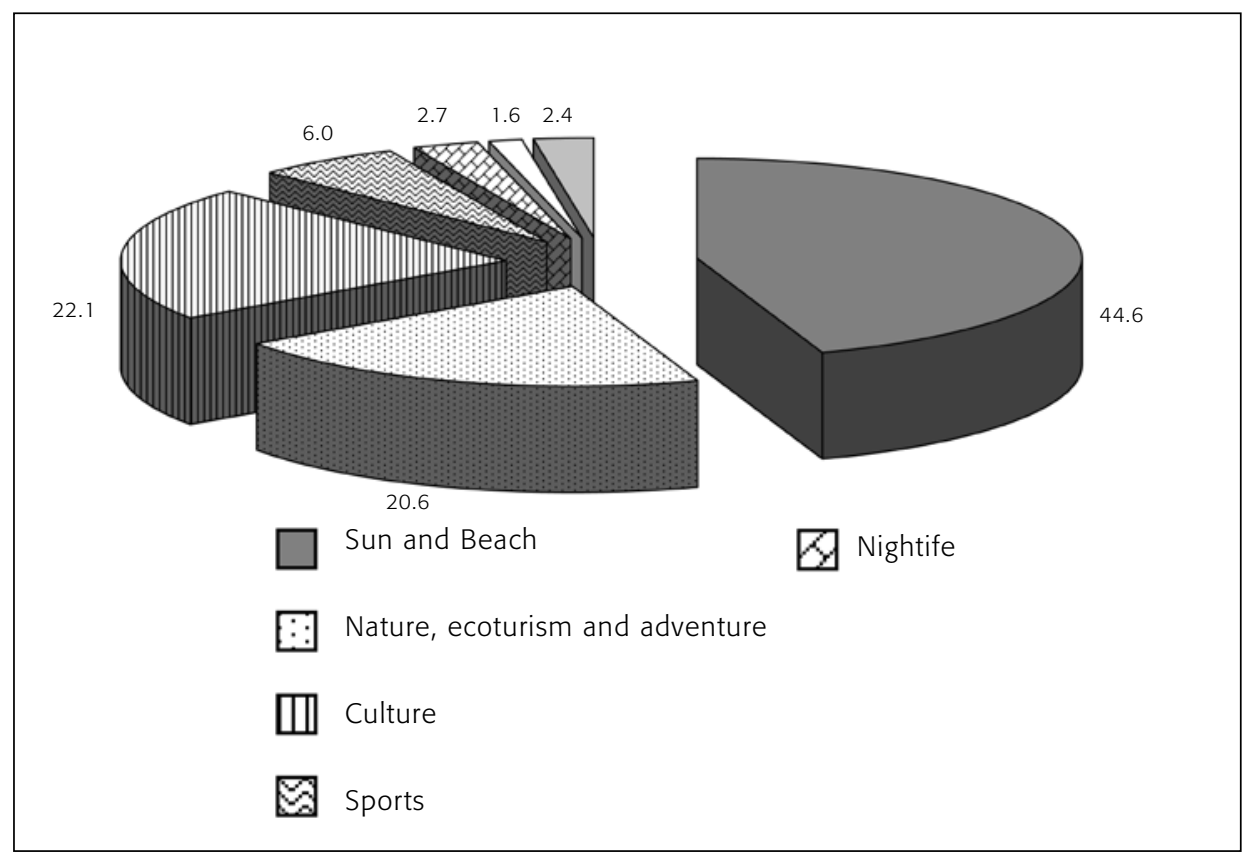

Source: Fipe (2008).

According to the Fipe's Domestic Demand Survey (2002-2006) the main touristic flow to the municipalities of Rio de Janeiro is provided by intrare- 
gional tourism from the states of São Paulo, Minas Gerais and Espírito Santo, the same study reveals that a total of 50.9 million internal trips were made in 2005. Rio de Janeiro is one of the country's most important states in terms of domestic receptive tourism, totaling $8.7 \%$ of domestic demand. Table 1 shows the main means of accommodation used in domestic tourism, with hotels, inns and resorts taking second place, a factor which confirms their importance in percentage terms - 20.8\% in 2005 - and highlights their growth potential in the hospitality sector.

\section{Table 1}

Main means of accomodation using during the domestic trip, by destination region (\%) in 2001 and 2005

\begin{tabular}{|lcc|}
\hline Means of accommodation & \multicolumn{2}{c|}{ Southeast region } \\
\hline House of friends or relatives & 2001 & 2005 \\
Hotel, inn or resort & 63.3 & 62.7 \\
Rented house/apartment & 18.9 & 20.8 \\
Own house/apartment & 7.5 & 7.2 \\
Holiday camp & 5.6 & 4.9 \\
Camping site or hostel & 2.4 & 2 \\
Motel or guest house & 1.1 & 0.6 \\
Others & 0.4 & 0.2 \\
Total & 0.9 & 1.6 \\
\hline
\end{tabular}

Source: Fipe (2006).

\section{Technological capability at the organizational level}

According Pavitt (1987), technology should be understood as a quantum of knowledge retained by people and organizations, with knowledge being the outcome of experience accumulated in projects, production and process development and improvement. This knowledge is mostly tacit and is not formerly recorded or documented in manuals, norms, technical publications or information systems

From an individual perspective, tacit knowledge is what certain people know how to do, but find it difficult to describe how they do it. This knowledge may be observed in the work of a kitchen chef or a concierge, whose results 
are achieved not only by applying recipes or manuals but are also due to experience acquired over time. At the organizational level and from a technological and corporate perspective, knowledge is both tacit and codified.

This knowledge, or technology, is conceived, developed and modified within specific organizational contexts, besides residing or accumulating in resources and components such as techno-physical systems, organizational and management structures and systems, in people, and in company products and services. The stock of resources that enables one or more organizations to perform technological activities in an independent fashion is entitled technological capability (Figueiredo, 2009).

Thus, technological capability is defined as a stock of knowledge-based resources that is stored in four components (Bell and Pavitt, 1993, 1995; Figueiredo, 2001, 2009):

v techno-physical systems - technological capability is accumulated and incorporated into physical systems that people build over time, such as equipment, software, databases etc.;

- organizational and management structure and systems - capabilities are incorporated and accumulated particularly in the organizational structure or system of the firm (or firms) they come from. The firm, over time, develops a set of routines that derive from the way it conducts its activities. For example, after trying out (error and learn) various ways of receiving guests, the firms chooses a sequence of actions which assure the desired result. By performing this sequence over time, the firm not only improves it but also embeds peoples' knowledge, and the way things are done in that particular firm, in it. Thus, as processes and services derived from organizational routines are very firm specific, it is difficult for others to replicate them. That is, insofar as firms are engaged in activities that seek out new activities and solutions for technical and organizational problems, they embed specific and intrinsic knowledge in their routines. This organizational knowledge is tacit in nature;

v in people - another part of a firm's technological capability is incorporated into the minds of specialized professionals and other people in the organization. This dimension of capability is expressed through their formal education and learning, but mainly their accumulated experience, skills, adroitness and accumulated talents, in other words, the key elements of their tacit knowledge;

v products and services - another part of a firm's capability is incorporated into the products and services that are designed, developed, manufactured, 
supplied and commercialized by the firm based on its techno-physical systems, people and organizational system. Products and services should not be regarded merely as the "results" of the other three components. They express part of the firm's technological capability.

It should be observed that there is an inseparable relationship between the four components (figure 12), indicating that technological capability is intrinsic and specific to a firm or country. However these four components vary as to their degree and order of importance. In the context of developing countries like Brazil, the "human resources" and "organizational and management systems" components are more important than techno-physical systems and products and services. Technical-physical systems (machines, equipment and software) are available in the market and can be purchased by firms. However, organizational systems (due to the specificity of organizational routines) and human resources are not easily tradable. These components must be developed internally and require corporate management's special attention and effective efforts (Figueiredo, 2009).

Figure 11

Technological capability dimensions

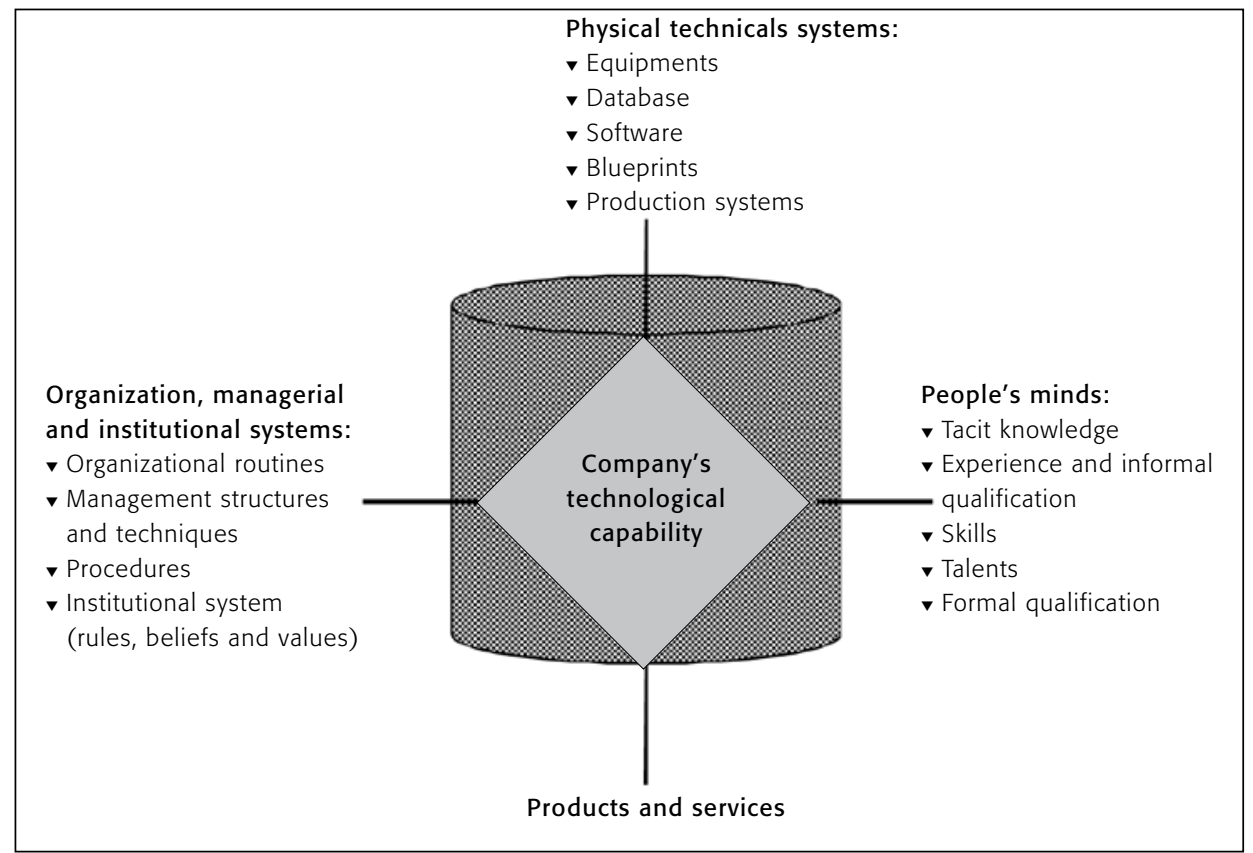

Source: Figueiredo (2005). 
Depending on their level of technological capability accumulation, firms may perform activities involving the use or operation of technologies that are already available in the market (operational technological capabilities), or modify existing technologies and generate new service production technologies (innovative technological capabilities). Thus, regarding the technological capability to undertake a specific activity, at both firm and country level, it is important to identify the type (production/operation or innovation) and what degree or level has been attained (Bell, 1982; Figueiredo, 2004, 2009). Moreover, from an organizational or country strategy point of view, it is important to observe the manner and speed with which firms and institutions build and accumulate their technological capabilities, especially their innovative capability. Organizations' firm commitment to the accumulation of technological capabilities is a determining factor in enhancing their competitive and innovative capability in the sector in which they operate.

\section{The nature of innovation, its characteristics and particularities}

This study, in line with the concepts developed by Joseph Schumpeter (1911, reported by Figueiredo, 2009), defines innovation, in general, as the introduction of new products, production processes, opening up of new markets, development of new sources of raw material and other input supplies, creation of new market structures, that pay for the original investment in their development as well as providing additional returns. Thus, innovation involves more than just creativity, but also embraces the development of new products, services, processes or institutional arrangements.

\section{Various perspectives on innovation in services}

As argued by Hjalager (2010), most studies of innovation in tourism depend on exploratory and qualitative cases (Kumar, 2008; Klemente and Yu, 2007; Novelli, 2005; Orfila-Sintesa and Crespi-Cladera, 2004, 2007; Alves, 2009; Hall, 2009). Although firms in the touristic services sector innovate, their research and acquisition of knowledge for the innovation process is still undertaken quite informally and they have only a limited understanding of the innovative technological capability acquisition process. Our knowledge of the dynamics of innovation processes in tourism firms is incomplete.

Knowledge management itself is still not considered to be a significant discipline in business tourism. Businessmen and managers in the tourism sec- 
tor state that they are too busy to innovate and do not have qualified personnel (Hajalager, 2010). Although the results presented by studies of policies towards tourism are taken into account in research on innovation in the sector, there is a need to reemphasize the production of academic knowledge and its dissemination and application in the market. Aligned with the Schumpeterian perspective, exploratory studies of tourism define innovation as the creation of new possibilities for adding value to the product, focusing not only on the product itself or product process innovation, but also the market and organizations (Martínez-Ros and Orfila-Sintes, 2009).

When analyzing the innovation process in tourism sector industries, the literature highlights two difficulties: on the one hand the fact that innovation theory has been based essentially on the analysis of technological innovation in manufacturing industry, and on the other, the specific properties of service activities, especially the nature of production, which makes it particularly difficult to measure its productivity (Orfila-Sintes, 2009).

These services have specific characteristic that differentiate them from manufactured products (chart 1 ).

Chart 1

Main characteristics identified during the provision of a service

\begin{tabular}{|ll|}
\hline \multicolumn{1}{|c|}{ Characteristic } & \multicolumn{1}{c|}{ Description } \\
\hline Intangibility & After "consuming" a service there is no physical manifestation of what \\
& has been supplied. Customers do not possess anything tangible as a \\
& result of buying the service. For example, after a customer has consumed \\
& a service like air transport, he/she is left at the destination with nothing \\
& physical (besides the ticket) to show for the expenditures. \\
& Given their simultaneous consumption and production, services are per- \\
Perishability & ishable and cannot be "stored" in a format for subsequent delivery. \\
Heterogeneity & Each service encounter is somewhat unique and the particular service that \\
& is being purchased is not produced (for verification by the customer or \\
& another person) before the consumption date. Moreover, personalization \\
creates heterogeneity in the customer and produces expectations. & Services are simultaneously produced and consumed. Customers are, \\
thus unable to see or try out the actual service they will receive before \\
delivery. Most services are also consumed in the same locality where \\
they were produced. \\
Customers may develop expectations regarding service that they transfer \\
to all sectors. \\
Customers and service providers are inclined to have cultural expecta- \\
tions and values that will affect their respective interpretations of the \\
service encounter.
\end{tabular}


Thus, the literature indicates certain characteristics of the innovation process in tourism service activities:

v innovations in tourism are usually both technical and behavioral in nature. These aspects vary in degree but do not exclude each other;

v in service innovations, the process cannot be completely separated from the product, because the product is the process;

v innovative capability depends on the ability to exploit and mobilize a broad range of knowledge and techniques, with implications for the flow's social forms and the ownership of information and knowledge. In addition to knowledge from the exact sciences, other fields of knowledge play an important role, such as linguistics, cognitive sciences and operational research methods;

v innovation clusters that emerge from different service sectors are combined in such a way as to constitute systems. Initially independent groups of services develop ties with each other, thus forming a system. This is typical among transportation firms, catering services, tourist agencies, leisure services etc.;

- in organizations of R \& D in service processes, new combinations of capabilities or features may entail new combinations of individuals (particularly when the expertise is highly tacit). Thus there is a tendency to establish flexible project groups to manage innovation in service companies.

\section{A broader perspective on innovation}

The understanding of innovation has evolved over the years, in tandem with changes in the nature of technological knowledge and the way it is managed. There are various kinds and degrees of innovation. It may emerge initially during simple activities, as a copy, imitation or experimentation, or in more complex and sophisticated activities, that involve research and development (R\&D). Thus innovation should be understood as a process and not as a series of isolated events.

The various types and degrees of innovation range from the most basic ones, involving small changes in processes and equipment/systems, based on the imitation or copying of existing technologies that are new to the firm, to 
incremental changes, involving more sophisticated changes or the introduction of new processes for the market in which the firm operates, and finally the so-called radical changes, where firms introduce new concepts to the world market (Figueiredo, 2009).

The current perspective on innovation involves the implementation of integration systems and network operating models, in which firms develop close links with customers and suppliers, form joint ventures and establish collaborative research groups and marketing arrangements etc. The emphasis is on corporate flexibility, the speedy development of new products and processes, as well as a focus on quality and other non-price factors (Rothwell, 1994).

\section{Characteristics of the innovation process}

As mentioned above, innovative activities are the outcome of an innovation process. According to Dosi (1988), the innovation process has the following properties:

v uncertainty is inherent to the innovation process;

- increasing dependence on scientific knowledge (the more advanced levels);

v organizational formality of the innovation process;

v informality is also part of the innovation process;

$\checkmark$ cumulativeness.

Firstly, the innovation process is characterized not only by the prior lack of information but also by the impossibility of identifying the consequences and results of research and experimentation activities, such that technological innovations are the product of a trial and error process.

The second characteristic of the innovation process is the growing use of scientific advances and discoveries as technological opportunities. Although science was originally primarily concerned to explain the nature's phenomena, it gradually began to also devote itself to explaining issues related to machines and processes created by the man himself. As from the end of the $19^{\text {th }}$ century, technology began to make significant use of science, leading to the development of new machines, processes and products based on the advances of scientific knowledge, a chronological inversion of the chain linking science 
and technology. Science goes to meet the technology not only to specific findings, but also with the increasingly wide use of research in solving problems of the productive sector (Figueiredo, 2009).

The third property concerns the increasingly important role of organizational arrangements in fostering an innovative environment, as opposed to the traditional view that innovation is only generated by a few individuals or specialized organizational units.

Also highlighted is the importance of "informal" problem-solving activities, catering to user specifications and small changes to meet distinct needs. These activities are usually performed on a "learning-by-doing" and "learningby-using" basis.

The last property involves the cumulative nature of the innovation process, characterized as a continuous learning process, where the nature of technologies in use defines the directions of technological change. Thus, the capacity to realize technological advances is a function of the technological levels already attained by the organization. However, the appearance of radical innovations does not destroy prior knowledge.

The innovation process also varies according to economic sectors, and these specificities prevent meaningful comparisons between firms in different sectors. Naturally, these differences determine the nature of the innovation process inside firms. Thus, there are differences in the degree of difficulty and complexity of the innovation process' technological capability.

\section{A technological capability framework for hospitality industry: hotel service firms}

This study adopts the strategy of measuring technological capability according to types and levels. The framework presented in chart 4 divides technological capability levels into operational capabilities and innovation capabilities, at firm level.

The framework also identifies four technological functions, representing the groups of activities that were regarded as essential and able to incorporate the most significant innovation levels in the firms to be examined.

The framework proposed encompasses the following technological functions (chart 2). 
Chart 2

Description of technological functions related to the framework applied to hospitality industry

\begin{tabular}{|c|c|}
\hline Technological function & Description \\
\hline $\begin{array}{l}\text { Services, governance } \\
\text { and hospitality }\end{array}$ & $\begin{array}{l}\text { Room reservation registration, guest registration, customer service, internal and } \\
\text { external communications for guests and related services, control of products } \\
\text { and services with room access, visual control of entry and exit of guests and } \\
\text { visitors, concierge and governance services. }\end{array}$ \\
\hline $\begin{array}{l}\text { Entertainment, leisure } \\
\text { and business }\end{array}$ & $\begin{array}{l}\text { Development, coordination and organization of leisure activities, meetings } \\
\text { and conventions, specific stock control, preparation of acceptance and quality } \\
\text { reports and specific training for leisure and entertainment services. }\end{array}$ \\
\hline $\begin{array}{l}\text { Food and beverage } \\
\text { operations }\end{array}$ & $\begin{array}{l}\text { Management of food and beverage activities, organization of banquets, } \\
\text { kitchen, pantry and bar management, production of meals, catering to requests } \\
\text { for food, knowledge of beverages and their storage and production. }\end{array}$ \\
\hline $\begin{array}{l}\text { Hotel services } \\
\text { management }\end{array}$ & $\begin{array}{l}\text { Human resources management, education and training, internal and external } \\
\text { communications services (TIC), management of inputs and products used in } \\
\text { hotel operations, purchase of goods, preventive and corrective maintenance, } \\
\text { budgeting and auditing processes, capturing customers, market surveys, } \\
\text { advertising of goods and services, sales, discounts and promotions. }\end{array}$ \\
\hline
\end{tabular}

The technological capability framework has five technological capability levels (chart 4) for each function defined in chart 3. The first two levels (one and two) represent the capability to perform activities that are routine or based on an existing and consolidated technology. The three other levels correspond to innovative capabilities, with the first (level three) corresponding to activities that are able to generate innovations at firm level, the second (level four) encompassing activities that generate innovation at the regional or national level, and the last level (level five) representing the firm's innovative capability at a world level.

Chart 3

\section{Description of technological capability levels used in the technological capability framework applied to hospitality industry}

\begin{tabular}{|ll|}
\hline $\begin{array}{l}\text { Technological } \\
\text { capability level }\end{array}$ & \multicolumn{1}{c|}{ Description } \\
\hline $\begin{array}{l}\text { Level 5 } \\
\text { Advanced innovator }\end{array}$ & $\begin{array}{l}\text { Ability to develop large-scale events for tourism: award ceremonies, product } \\
\text { launches, media campaigns, Develop products in partnership with hotel equip- } \\
\text { ment and systems suppliers. Develop projects integrated with the tourist trade, } \\
\text { international customer portfolio management. Development of projects for the } \\
\text { implementation of highly complex tourist attractions. }\end{array}$ \\
\hline
\end{tabular}

Continues 
Technological capability level

Level 4

Intermediate

innovator

Level 3

Basic innovator

Level 2

Advanced operational

Level 1

Basic operational

\section{Description}

Ability to develop waste treatment projects. Development and management of leisure and business activities. Management of domestic customer portfolio. Development of performance appraisal and specific personnel management training processes. Develop differentiated service (gastronomy, concierge, entertainment) projects with universities, institutions and specialized entities.

Specification, selection of suppliers and monitoring of the installation of infrastructure and resources for hotel operations. Provide basic special leisure and business services. Organization of banquet and events, with provision of resources and services by third parties. Customer profile management processes. Provision of complementary services with the support or participation of third parties. Development of service resources differentiated according to age-group or intermediate interests. Personalization and management of the deployment of hotel operationalization support equipment and systems. Domestic and international quality and operations certifications.

Ability to establish the conditions needed for food and beverage operations, in accordance with the standards accepted by the sector. Implement hospitality process quality assessment procedures. Perform hotel input and infrastructure management procedures. Provide security services for customers inside the hotel and its immediate vicinity. Provide communication services, on-line reservation and automated check-in and check-out facilities.

Ability to establish the conditions necessary for reception, service and lodging operations, in accordance with the standards accepted by the industry. 


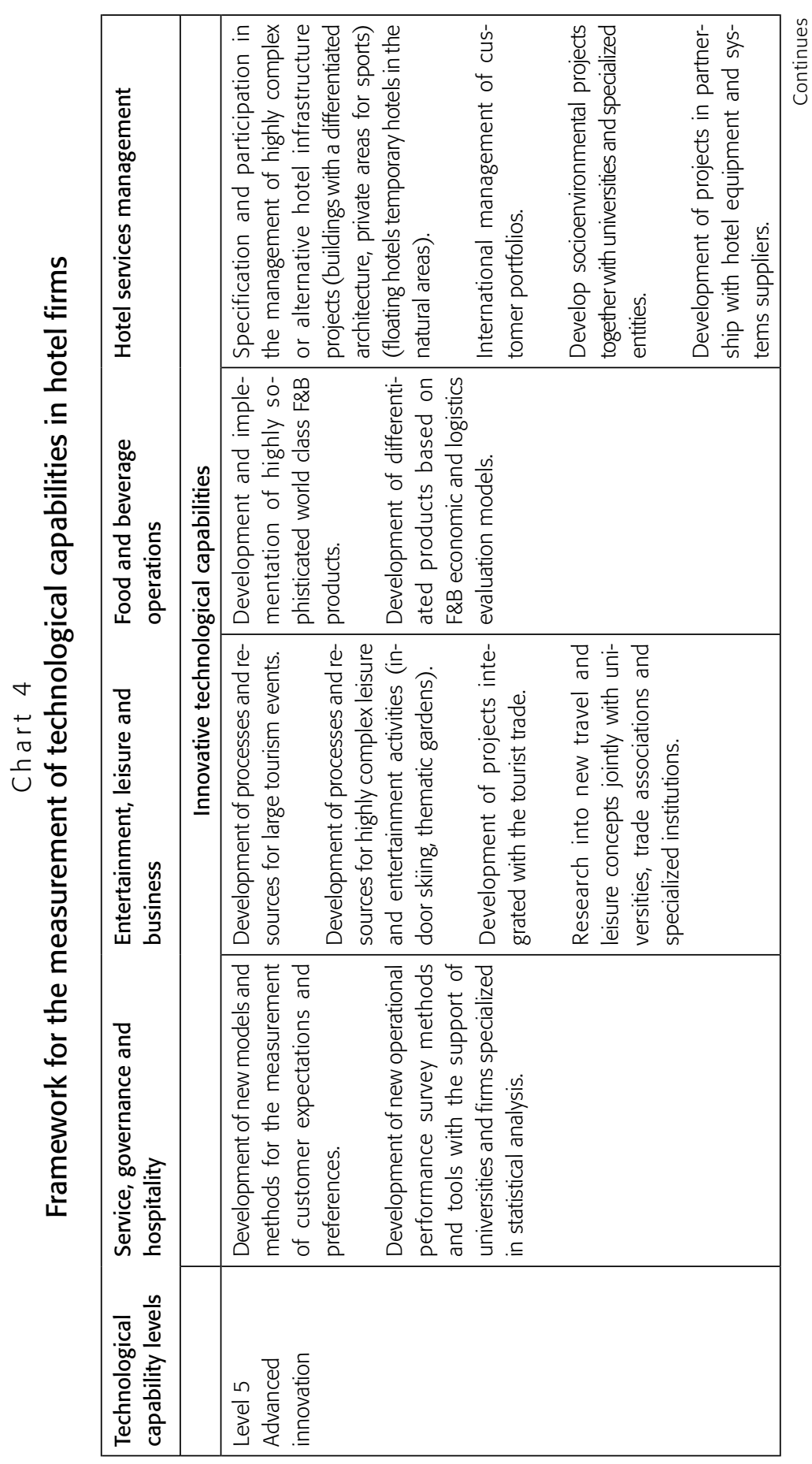

RAP - RIO DE JANEIRO 44(5):1139-170, SET./OUT. 2010 


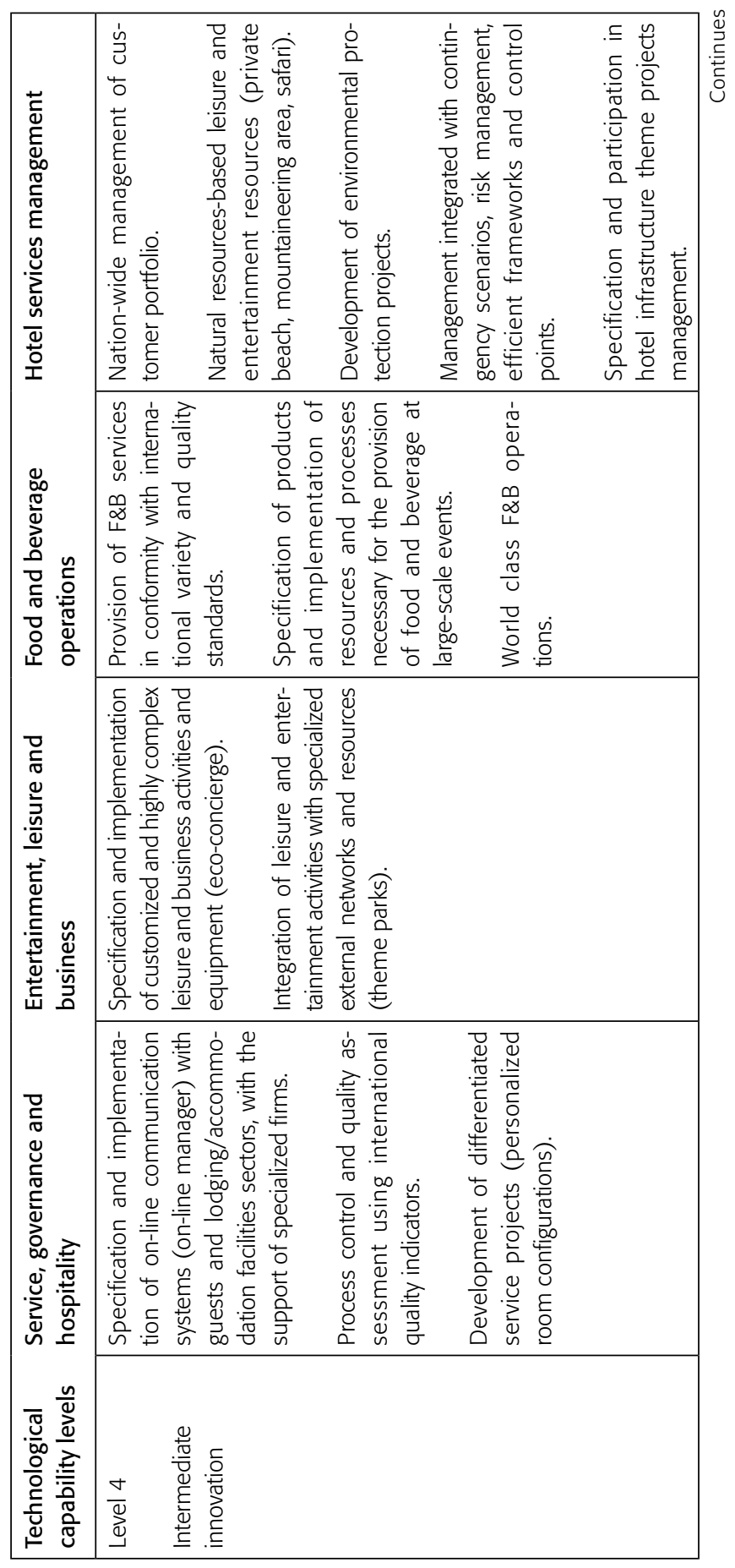




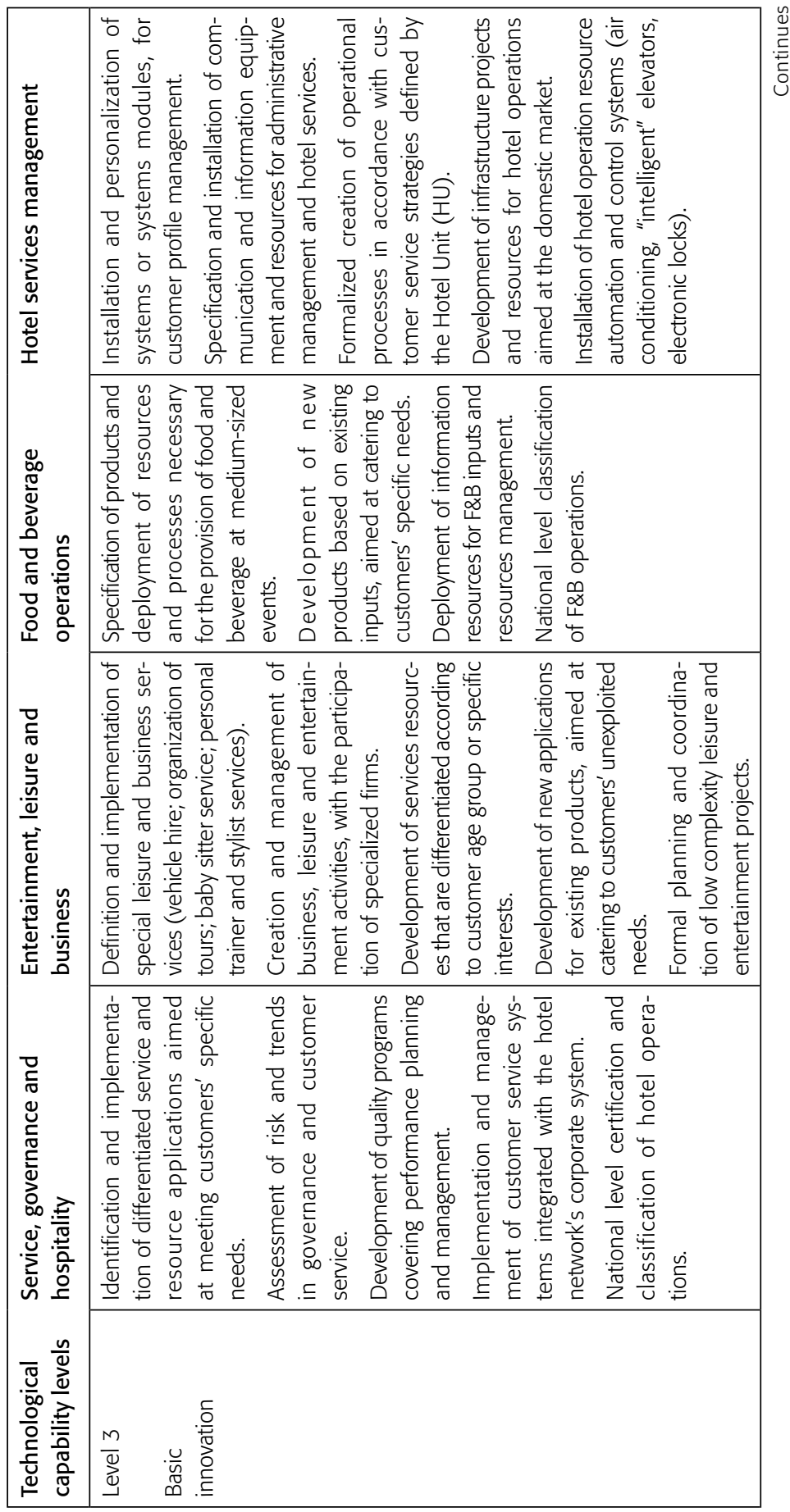




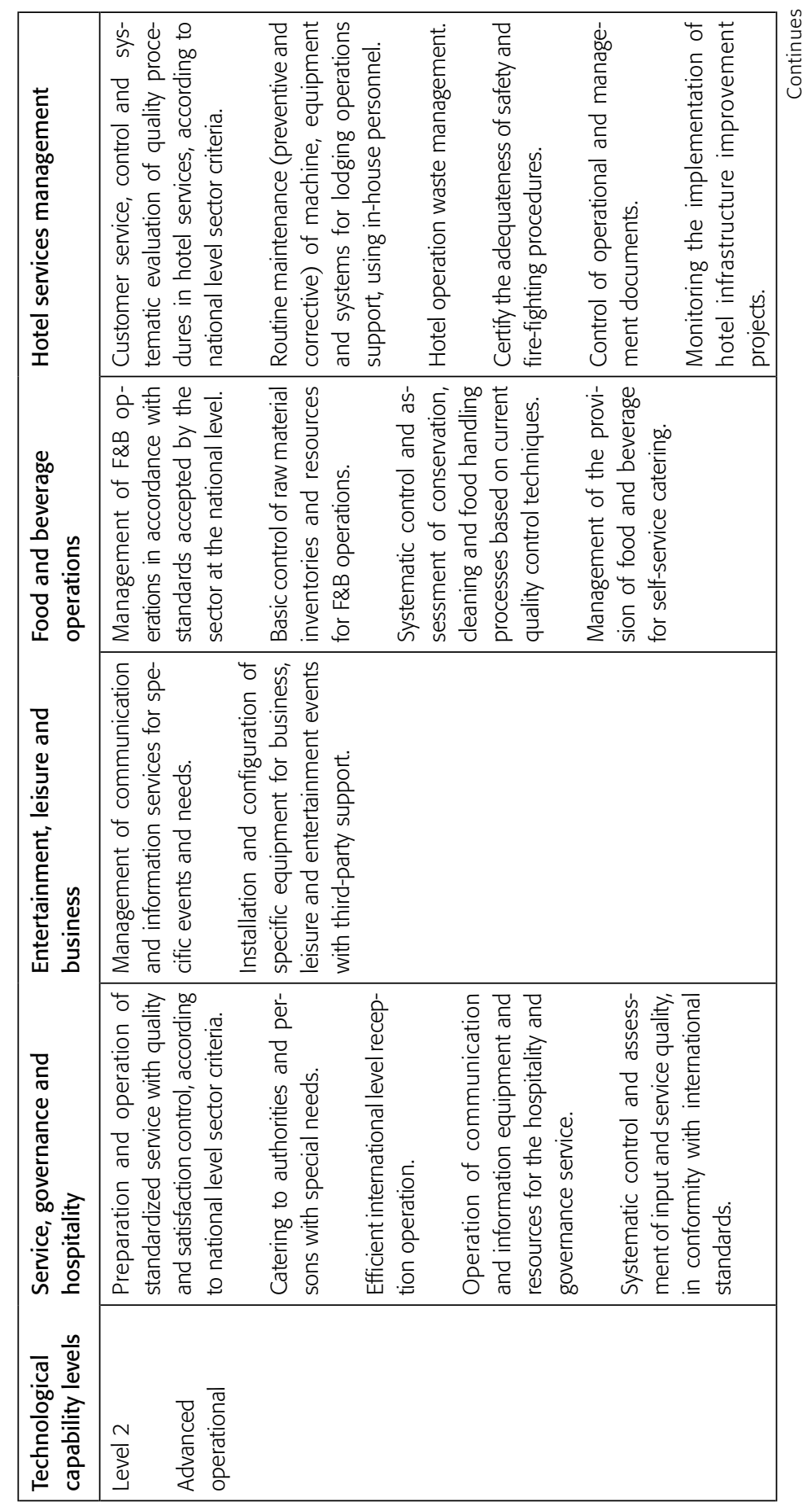




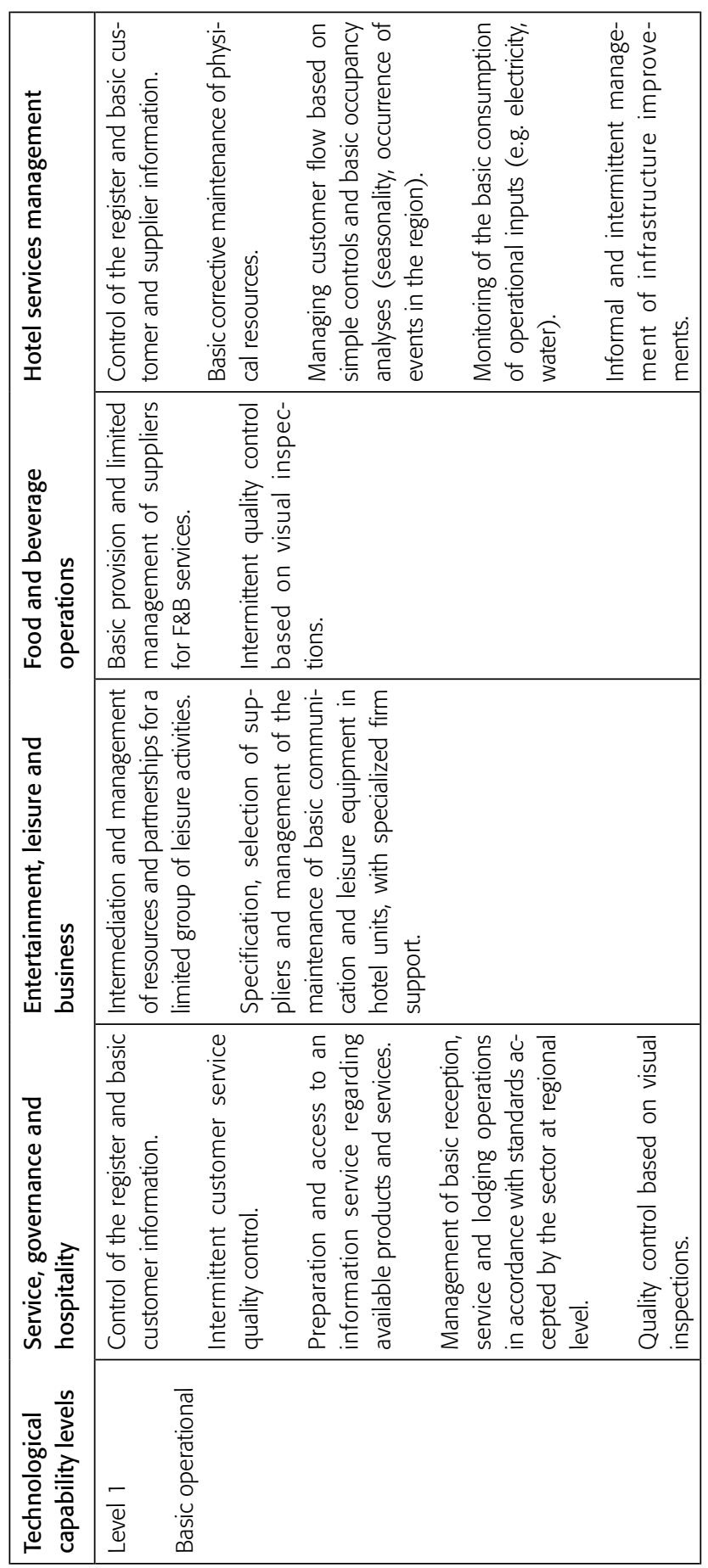




\section{Sources of technological capability accumulation}

The accumulation of technological capacity, whether at the operational or innovative level, requires firms' systematic development of learning processes (Figueiredo 2003, 2009), which can be divided into four types:

- external knowledge acquisition processes - these are processes through which individuals acquire tacit and/or codified knowledge from outside the firm. It is possible to obtain this external knowledge through technical assistance, taking part in conferences and events and promoting training programs abroad;

v internal knowledge acquisition processes - these are processes through which individuals acquire tacit knowledge performing different activities in the firm. This knowledge may be acquired while performing routine tasks, perfecting processes or when undertaking specific activities in formally organized R\&D centers or through systematic experimentation in various operational units;

- knowledge socialization processes - these are processes through which individuals share their tacit knowledge, transmitting it from one individual or group of individuals to another through meetings, joint problem solving and task rotation. Training programs can also constitute a knowledge socialization process;

v knowledge codification processes - processes through which tacit knowledge is expressed in explicit concepts in an accessible and organized way, thus facilitating their assimilation. This process makes it easier to disseminate knowledge throughout the firm and may be undertaken through the standardization of production methods, documentation and internal seminars.

The impact that learning processes may have on technological capability accumulation may be identified in terms of four characteristics: variety, intensity, functioning and interaction.

Variety is measured here in terms of the existence or lack of a whole process and other subprocesses derived from it (the standardization process). The variety is measured not only among the four learning processes, but also within them.

Intensity represents the frequency with which learning processes are created, up-dated, used and perfected over time. Intensity is important becau- 
se: it can assure a constant flow of external knowledge to the firm; can lead to a better understanding of the technology acquired and the principles inherent to internal knowledge acquisition processes; and can assure the constant conversion of individual learning into organizational learning and therefore its routinization.

Functioning involves the way learning processes operate over time. Although the intensity of processes may be continuous, they may not function well. They may function well initially but deteriorate over time. Functioning may contribute to increasing and/or decreasing "variety" and "intensity".

Interaction is the way different learning processes mutually influence each other. For example, a knowledge socialization process (an internal training program) may be influenced by an external knowledge acquisition process (a training program abroad).

\section{Framework to examine technological capability accumulation sources}

Intraorganizational learning processes will be examined in this study as one of the key sources for capability building and accumulation. The assessment of learning processes will be performed using the framework presented in chart 5 .

Chart 5

Characteristics of the external and internal knowledge acquisition processes

\begin{tabular}{|c|c|c|c|c|}
\hline \multirow[b]{3}{*}{$\begin{array}{l}\text { LEARNING } \\
\text { PROCESSES }\end{array}$} & \multicolumn{4}{|c|}{ KEY FEATURES OF THE LEARNING PROCESSES } \\
\hline & VARIETY & INTENSITY & FUNCTIONING & INTERACTION \\
\hline & $\begin{array}{c}\text { Absent - Present } \\
\text { (Limited - Moderate - Wide) }\end{array}$ & $\begin{array}{l}\text { On-Off - Intermittent } \\
\text { Continuous }\end{array}$ & Poor - Moderate - Good - Excellent & Weak - Moderate - Strong \\
\hline \multicolumn{5}{|c|}{ KNOWLEDE-ACQUISITION PROCESSES AND MIECHANISUS } \\
\hline $\begin{array}{l}\text { EXTERNAL } \\
\text { KNOWLEDGE } \\
\text { ACQUISITION }\end{array}$ & $\begin{array}{l}\text { Absence presence of processes for } \\
\text { acquiring lonowledge locally and or } \\
\text { overseas (e. . pulling in expertise } \\
\text { from outside, overseas training) } \\
\text { Diverse variety may bring different } \\
\text { expertise into the company. }\end{array}$ & $\begin{array}{l}\text { The way the company makes use of } \\
\text { this process may be continuous (e.g } \\
\text { overseas training for engineers and } \\
\text { operators annually. , intermittent or } \\
\text { even one -off (e. . interrupting } \\
\text { overseas training). }\end{array}$ & $\begin{array}{l}\text { The way a process is created (e.g. criteria to } \\
\text { sead individuals to overseas training) and } \\
\text { the way it works over time may strengthen } \\
\text { or mitigate variety and intensity. Timing. } \\
\text { 'learning-before-doing'. }\end{array}$ & $\begin{array}{l}\text { The way a process infuences gther. } \\
\text { extermal or intemal inowledge- } \\
\text { acquistition processes (overseas } \\
\text { training, "learning-by-doing') and of } \\
\text { other knowledge coaversion. } \\
\text { processes. }\end{array}$ \\
\hline $\begin{array}{l}\text { INTERNAL } \\
\text { KNOWLEDGE } \\
\text { ACQUISITION }\end{array}$ & $\begin{array}{l}\text { Absence presence of processes for } \\
\text { acquiring lnowledge by doing in- } \\
\text { bouse activities (eg. "capacity- } \\
\text { stretching', plant experimentation). } \\
\text { These may be routine operational } \\
\text { and or innovative activities (e. \&. } \\
\text { product development) }\end{array}$ & $\begin{array}{l}\text { The way the company makes use of } \\
\text { different processes for internal } \\
\text { inowledge acquisition. This may } \\
\text { infuence the individuals' } \\
\text { understanding of the principles } \\
\text { involved in the technology. }\end{array}$ & $\begin{array}{l}\text { The way a process is created (e.g. research } \\
\text { centres), and the way it works over time } \\
\text { bave practical implications for variety and } \\
\text { intensity. Timing: 'learning -before- doing'. }\end{array}$ & $\begin{array}{l}\text { Internal knowledge acquisition may } \\
\text { be triggered by external knowledge } \\
\text { acquistion process (e.g. plant } \\
\text { inprovements triggered by overseas } \\
\text { training). This may trigger } \\
\text { knowiedge-conversion processes. }\end{array}$ \\
\hline \multicolumn{5}{|c|}{ KNOWLEDGE-CONVERSION PROCESSES AND MIECHANISIIS } \\
\hline $\begin{array}{l}\text { KNOWLEDGE } \\
\text { SOCLALISATION }\end{array}$ & $\begin{array}{l}\text { Absence preseace of different } \\
\text { processes whereby individuals share } \\
\text { their tacit lonowledge (e.g. meetings, } \\
\text { shared problem-solving, OJT). }\end{array}$ & $\begin{array}{l}\text { The way processes like supervised } \\
\text { OfT are continued over the years. } \\
\text { Continuous inteasity of knowiedge } \\
\text { socialisation may trigger lonowledge } \\
\text { codification. }\end{array}$ & 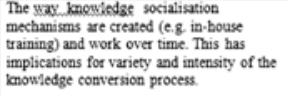 & $\begin{array}{l}\text { Bringing differeat tacit knoweledse. } \\
\text { inte a workable system (e. creating } \\
\text { knowiedge links). Socialisation may } \\
\text { be infuenced by external or internal } \\
\text { knowledge-acquastion processes. }\end{array}$ \\
\hline $\begin{array}{l}\text { KNOWLEDGE } \\
\text { CODIFICATION }\end{array}$ & $\begin{array}{l}\text { Absence presence of different } \\
\text { processes and mechanismas to codify } \\
\text { tacit knowiedge (e.8. systematic } \\
\text { documentation, internal seminars etc.) }\end{array}$ & $\begin{array}{l}\text { The way processes like operations } \\
\text { standardisation are repeatedly done. } \\
\text { Absent of intermittent codifieation } \\
\text { may limit organisational learning. }\end{array}$ & $\begin{array}{l}\text { The way knowledge codification is created } \\
\text { and works over time has implications for } \\
\text { the functioning of the whole knowiedge. } \\
\text { conversion process. This also influences } \\
\text { variety and intensity of the process. }\end{array}$ & $\begin{array}{l}\text { The way knowledge codification is } \\
\text { influenced by knowledge acquisition } \\
\text { prosesses. (e. g. overseas training) of } \\
\text { by other knowledge-socialisation } \\
\text { processes (e.g team building). }\end{array}$ \\
\hline
\end{tabular}

Source: Figueiredo (2001, 2003). 


\section{Final considerations}

Kumar, Kumar e Grosbois (2008) emphasizes that the main recommendation for hospitality organizations interested in developing their technological capability through innovation is to concentrate on supporting a learning culture. Management skills, project management, an organizational learning culture and government support are fundamental for developing a technological accumulation capability. We perceive that people have an important role to play in the development of technological competencies in the hospitality industry, a characteristic that, as various analyses have shown, is shared with other service sectors.

Thus, this project's aim is to provide evidence and recommendations so that the city of Rio de Janeiro's tourism sector can increasingly strengthen its competitive capacity and also provide other Brazilian regions with a methodology to assess their innovative capability, thus helping them to prepare corporate strategies and develop new policies designed to support their local hospitality sectors.

\section{References}

BELL, M. Technical change in infant industries: a review of the empirical evidence. Brighton: SPRU, University of Sussex, 1982.

.; PAVITT, K. Technological accumulation and industrial growth: contrasts between developed and developing countries. Industrial and Corporate Change, v. 2, n. 2, p. 157- 211, 1993.

; . The development of technological capabilities. In: UL HAQUE, I. et al. Trade, technology and international competitiveness. Washington, DC: The World Bank, 1995.

BRASIL. Ministério do Turismo. Plano nacional de turismo 2003-2007. Brasília, DF, 2003.

. Ministério do Turismo. Meios de hospedagem: estrutura de consumo e impactos na economia. Brasília, DF, 2006. 2007a.

. Ministério do Turismo. Plano nacional de turismo 2007-2010. Brasília, DF,

. Ministério do Turismo. Estudo de competitividade dos 65 destinos indutores do desenvolvimento do turismo regional - Relatório Brasil. Brasília, DF, 2007b. 
. Ministério do Turismo. Estudo da demanda turística internacional 20052007. Brasília, DF, 2009a.

. Ministério do Turismo. Pesquisa anual da conjuntura econômica do turismo - 2009. Brasília, DF, 2009b.

. Ministério do Turismo. Pesquisa anual da conjuntura econômica do turismo -2010. Brasília, DF, 2010.

DOSI, G. The nature of the innovative process. In: et al. (Eds.). Technical change and economic theory. London: Pinter Publishers, 1988.

EMPRESA BRASILEIRA DE INFRAESTRUTURA AEROPORTUÁRIA (INFRAERO). Superintendência de Planejamento e Gestão. Movimento Operacional Acumulado da Rede Infraero 2010 - 2003. Available at: <www.infraero.gov.br>. Accessed on: March 18 $8^{\text {th }}, 2010$.

ENZ, C. A.; SIGUAW, J. A. Innovations in hotel practice. Cornell Hotels and Restaurant Administration Quarterly, n. 44, p. 115-123, 2003.

FIGUEIREDO, P. N. Technological learning and competitive performance. Cheltenham, UK/ Northampton, MA: Edward Elgar Publishing, 2001.

. Aprendizagem tecnológica e inovação industrial em economias emergentes: uma breve contribuição para o desenho e implementação de estudos empíricos e estratégias do Brasil. Revista Brasileira de Inovação, v. 3, n. 2, jul./dez, 2004.

. Acumulação tecnológica e inovação industrial: conceitos, mensuração e evidências no Brasil. São Paulo em perspectiva, v. 19, n. 1, p. 54-69, jan./mar. 2005.

. Gestão da inovação: conceitos, métricas e experiências de empresas no Brasil. Rio de Janeiro: LTC, 2009.

GALLOUJ, F. Innovating in reverse: services and the reverse product cycle. European Journal of Innovation Management, v. 1, n. 3, p. 123-138, 1998.

1997.

; WEINSTEIN, O. Innovation in services. Research Policy, n. 26, p. 537-556,

HALL, C. M. Innovation and tourism policy in Australia and New Zealand: never the twain shall meet? Journal of Policy Research in Tourism, Leisure and Events, v. 1, n. 1, p. 2-18, 2009.

HJALAGER, A. M. Innovation patterns in sustainable tourism: an analytical typology. Tourism Management, n. 18, p. 35-41, 1997.

HJALAGER, A. A review of innovation research in tourism. Tourism Management, v. 31, issue 1, p. 1-12, Feb. 2010. 
INSTITUTO BRASILEIRO DE GEOGRAFIA E ESTATÍSTICA (IBGE). Diretoria de Pesquisas. Coordenação de Contas Nacionais. Economia do turismo: uma perspectiva macroeconômica 2000-2005. Estudos e pesquisas. Informação Econômica, n. 9, Rio de Janeiro, IBGE, 2008a.

. Diretoria de Pesquisas. Coordenação de Contas Nacionais. Economia do turismo: análise das atividades características do turismo - 2003. Estudos e Pesquisas. Informação Econômica, n. 10, Rio de Janeiro: IBGE, $2008 \mathrm{~b}$.

. Diretoria de Pesquisas. Coordenação de Contas Nacionais. Economia do turismo: uma perspectiva macroeconômica 2003-2006. Estudos e Pesquisas. Informação Econômica, n. 12, Rio de Janeiro: IBGE, 2009.

KLEMENT, C. Inovação em serviços: estudo de casos em uma organização da indústria hoteleira brasileira. 214 p. 2007. Thesis (PhD) — Programa de Pós-Graduação em Administração, Faculdade de Economia, Administração e Contabilidade (FEA), Universidade de São Paulo, São Paulo.

KUMAR, U.; KUMAR, V.; GROSBOIS, D. Development of technological capability by Cuban hospitality organizations. International Journal of Hospitality Management, n. 27, p. 12-22, 2008.

NOVELLI, M.; SCHMITZ, B.; SPENCER, T. Networks, clusters and innovation in tourism: a UK experience. Tourism Management, v. 6, n. 27, p. 1141-1152, 2006.

ORFILA-SINTES, F.; CRESPI-CLADERA; MARTINEZ-ROS, E. Innovation activity in the hotel industry: evidence from Balearic hotels. Tourism Management, v. 6, n. 26 , p. $851-865,2005$.

; MATTSSON, J. Innovation behavior in the hotel industry. Omega, v. 2, n. 37, p. 380-394, 2007.

OTTENBACHER, M.; GNOTH, J. How to develop successful hospitality innovation. Cornell Hotels and Restaurant Administration Quarterly, v. 2, n. 46, p. 205-222, 2005a.

; SHAW, V.; LOCKWOOD, A. An investigation of factors affecting innovation performance in chain and independent hotels. Journal of Quality Assurance in Hospitality \& Tourism, n. 6, p. 113-128, 2005b.

PAVITT, K. The objectives of technology policy. Science and Public Policy, v. 14, n. 4, p. 182-188, 1987.

ROTHWELL, R. Towards the fifth-generation innovation process. International Marketing Revue, v. 11, n. 1, 1994. 
SIGALA, M. The information and communication technologies productivity impact on the UK hotel sector. International Journal of Operations \& Production Management, v. 23, n. 10, p. 1224-1245, 2003.

SORENSEN, F.; SUNDBO, J.; ORFILA-SINTES, F. The innovative behavior of tourism firms - comparative studies of Denmark and Spain. Research Policy. v. 36, p. 88-106, 2007.

SUNDBO, J. Management of innovations in services. The Service Industries Journal, v. 3, n. 17, p. 432-455, 1997a. 1997b.

; GALLOUJ, F. Innovation in services. Research Policy, v. 26, p. 537-556, ; _. Innovation in services. Services in Europe innovation system (SI4S), 1998. (Synthesis Paper).

TIDD, J.; HULL, F. M. (Eds.). Service innovation: organizational responses to technological opportunities \& market imperatives. London: Imperial College Press, 2003. 